\title{
CONF-960106--5
}

\section{EFFECT OF COMPOSITION ON THE PROCESSING AND PROPERTIES OF SINTERED REACTION-BONDED SILICON NITRIDE}

T. N. Tiegs, J. O. Kiggans, F. C. Montgomery, H. T. Lin, D. L. Barker, J. D. Snodgrass, E. M. Sabolsky and D. W. Coffey

Oak Ridge National Laboratory

P. O. Box 2008, Oak Ridge, TN 37831-6087

\section{INTRODUCTION}

Silicon nitride materials are the leading ceramics for structural applications at elevated temperatures because of their excellent combination of properties. However, cost is the major impediment for the use of silicon nitride in commercial applications. ${ }^{1}$ Sintered reaction-bonded silicon nitride (SRBSN) uses silicon powder as the raw material source and is an attractive alternative to the more conventional approaches that begin with $\mathrm{Si}_{3} \mathrm{~N}_{4}$ powders. ${ }^{2-6}$ Because of the low silicon powder cost, the process is cost-effective compared to the expensive high-purity powders. ${ }^{7}$

A significant amount of work on SRBSN has been done since the 1970's and a large database of information is available. ${ }^{2,3}$ However, within the last 10 years the level of research has been minor. In that same time period, a considerable amount of understanding on silicon nitride processing, microstructure development and property relationships has been established. The purpose of the present study was to examine the current state of SRBSN materials and determine the effect of different silicon precursor powders and different sintering additives on the processing and final mechanical properties.

The silicon powders are important because they determine to a large extent the overall purity of the system and the $\alpha-\mathrm{Si}_{3} \mathrm{~N}_{4}$ phase content developed during nitridation of the silicon. ${ }^{8}$ Much of the previous work reported in the literature used rather coarse Si powders $(>10 \mu \mathrm{m})$ and relatively low purity $(>0.5 \mathrm{wt} . \%$ $\mathrm{Fe}) .^{2-5}$ Considerably finer particle sizes and higher purity are presently available. The sintering additives also influence the $\alpha-\mathrm{Si}_{3} \mathrm{~N}_{4}$ phase content and, in addition, affect the microstructural development during densification. ${ }^{9}$ Most previous work on SRBSN employed $\mathrm{Y}_{2} \mathrm{O}_{3}$ and $\mathrm{Al}_{2} \mathrm{O}_{3}$ as the sintering additives. ${ }^{4-6}$ It is also well known that alternative sintering aids have been found to result in very different final material properties. ${ }^{9}$ Consequently, several alternative additives were 


\section{DISCLAIMER}

Portions of this document may be illegible in electronic image products. Images are produced from the best available original document. 
studied to see if they provided any advantage over the $\mathrm{Y}_{2} \mathrm{O}_{3}-\mathrm{Al}_{2} \mathrm{O}_{3}$ system in terms of densification, microstructural development or final properties.

\section{EXPERIMENTAL PROCEDURES}

The starting materials consisted of appropriate amounts of $\mathrm{Si}, \alpha-\mathrm{Si}_{3} \mathrm{~N}_{4}, \mathrm{Al}_{2} \mathrm{O}_{3}$, $\mathrm{MgO}, \mathrm{MgAl}_{2} \mathrm{O}_{4}$ and $\mathrm{Y}_{2} \mathrm{O}_{3}$ to give final compositions after nitriding as shown in Table 1. The silicon powders were chosen so that they represented a large variation in impurity content. The $\mathrm{Y}_{2} \mathrm{O}_{3}-\mathrm{Al}_{2} \mathrm{O}_{3}$ additive system was used as a base material because of the large database already established and it was also used to test the different silicon powders. SRBSN without the $\alpha-\mathrm{Si}_{3} \mathrm{~N}_{4}$ seed additive was tested because elimination of the seed is desirable since it represents a significant portion of the raw materials cost. ${ }^{7}$ The $\mathrm{MgO}-\mathrm{Y}_{2} \mathrm{O}_{3}$ additives were studied because they were reported to produce materials with very high fracture toughnesses. ${ }^{11}$ High toughness has also been reported for the $\mathrm{MgAl}_{2} \mathrm{O}_{4}-\mathrm{Y}_{2} \mathrm{O}_{3}$ additive system. ${ }^{12}$ Previous work on the $\mathrm{Y}_{2} \mathrm{O}_{3}-\mathrm{SiO}_{2}$ system showed that it resulted in materials that had good high temperature strength retention. ${ }^{13}$ All of the samples testing the alternative sintering aids used the same silicon powder (Elkem Metallurgical Grade).

The powders were turbomilled in isopropanol with $0.7 \mathrm{wt} . \%$ PVP $\mathrm{K}-15^{\mathrm{b}}$ and 1 wt.\% Darvan $821 \mathrm{~A}^{c}$ added as dispersants. The mixtures were dried, screened to 200 mesh and isopressed at $207 \mathrm{MPa}$ into discs approximately $7 \mathrm{~cm}$ in diameter and $2 \mathrm{~cm}$ thick. Binder burnout consisted of a heat-treatment to $550^{\circ} \mathrm{C}$ in air prior to sintering. The nitridation was carried out in either a tungsten-mesh or a graphite-resistance furnace with a $\mathrm{N}_{2}-4 \% \mathrm{H}_{2}$ gas flow and controlled heating to $1450^{\circ} \mathrm{C}$. The samples were then sintered in a graphite-element furnace with $\mathrm{Si}_{3} \mathrm{~N}_{4}$ packing powder under one atmosphere $\mathrm{N}_{2}$ to $1780-1800^{\circ} \mathrm{C}$ for 2 hours.

Densities were determined by the Archimedes method. Samples of high density were machined into bend bar specimens with nominal dimensions of $3 \mathrm{~mm} \mathrm{x} 4$ $\mathrm{mm} \times 50 \mathrm{~mm}$. Flexural strength testing was done in four point bending with inner and outer spans of $20 \mathrm{~mm}$ and $40 \mathrm{~mm}$, respectively. Fracture toughness was determined by an indentation and fracture method. Three batches of samples were fabricated and because the values were similar between batches, the results were averaged together to provide a more reliable set of data.

\section{RESULTS AND DISCUSSION}

After nitridation the $\alpha-\mathrm{Si}_{3} \mathrm{~N}_{4}$ phase contents were determined by $\mathrm{X}$-ray diffraction and the results are summarized in Fig. 1. As shown, for the different Si powders, the $\alpha$-content can be well correlated with the starting powder Fe content. This is similar to previous studies. ${ }^{8,9}$ The $\alpha$-content developed with alternate sintering aids shows significant differences with the higher $\alpha$-contents associated with the

b GAF Chemicals, Wayne, NJ: Polyvinylpyrrolidone K-15

${ }^{c}$ R. T. Vanderbilt, Norwalk, CT. 
$\mathrm{MgO}-\mathrm{Y}_{2} \mathrm{O}_{3}$ and $\mathrm{Y}_{2} \mathrm{O}_{3}-\mathrm{SiO}_{2}$ systems. The presence of the $\alpha-\mathrm{Si}_{3} \mathrm{~N}_{4}$ seed was found to enhance the formation of $\alpha$-phase during nitridation of the silicon.

As shown in Fig. 2, high densities were achieved for nearly ali of the samples with the exception of the $\mathrm{Y}_{2} \mathrm{O}_{3}-\mathrm{SiO}_{2}$ system. The sintering conditions had been selected to obtain high densities, however, the one set that did not sinter well was also the one that contained the most refractory of the grain boundary phases and therefore densification was marginal. All of the other materials had high enough densities to obtain mechanical property measurements.

The results on the room temperature flexural strength and fracture toughness for the various Si powder types are shown in Fig. 3. For the strength, a decrease was observed as the Fe content was also decreased. X-ray diffraction indicated that some unreacted $\mathrm{Si}$ was present in the samples from the highest purity $\mathrm{Si}$ powder. This unreacted Si may explain the lower strength and indeed, optical examination showed the fracture origins to be black spots that were most likely regions of unreacted $\mathrm{Si}$. The fracture toughness did not show any significant differences for the samples from the various Si types. Microstructurally, the higher Fe content silicon powders resulted in a slightly finer overall grain size as shown in a comparison of Figs. $4 \mathrm{a}$ and $\mathrm{b}$. The finer grain size is probably due to the higher starting $\alpha$-phase content after nitridation.

The results on the room temperature flexural strength and fracture toughness for the alternate sintering additives are shown in Fig. 5. High strengths and toughness were observed for the $\mathrm{Y}_{2} \mathrm{O}_{3}-\mathrm{Al}_{2} \mathrm{O}_{3}$ and $\mathrm{MgAl}_{2} \mathrm{O}_{4}-\mathrm{Y}_{2} \mathrm{O}_{3}$ containing materials. A relatively fine grain microstructure was observed with the $\mathrm{MgAl}_{2} \mathrm{O}_{4}{ }^{-}$ $\mathrm{Y}_{2} \mathrm{O}_{3}$ containing materials (Fig. 4d) and may help explain the good mechanical properties. The low strength and high toughness exhibited by the $\mathrm{MgO}-\mathrm{Y}_{2} \mathrm{O}_{3}$ samples is related to its lower sintered density. However, very large grains were observed with this system (Fig. 4e) which would also contribute to the high toughness and low strength. The samples without the $\alpha-\mathrm{Si}_{3} \mathrm{~N}_{4}$ seed addition had a slightly coarser grain microstructure as indicated by a comparison of Figs. 4 and c. The mechanical properties for the samples with alternative sintering aids correlated well with the starting $\alpha-\mathrm{Si}_{3} \mathrm{~N}_{4}$ contents as shown in Fig. 6.

The high temperature strength and strength retention are shown in Figs. 7 and 8. As shown previously, the room temperature strength for the different $\mathrm{Si}$ powders increased with increasing Fe content. However, the high temperature strength decreased more rapidly with the higher Fe content so that the samples made from higher purity Si had better strength retention.

Results on the weight gain during oxidation at $1000^{\circ} \mathrm{C}$ for 100 hours is shown in Fig. 9. Only the samples with $\mathrm{MgAl}_{2} \mathrm{O}_{4}-\mathrm{Y}_{2} \mathrm{O}_{3}$ additives showed any significant oxidation weight gain and that is most likely related to the low sintered densities of those materials. Flexural strength (measured at room temperature) after oxidation showed some decrease from the initial values for all samples except the one containing no added $\alpha-\mathrm{Si}_{3} \mathrm{~N}_{4}$ seed (Fig. 10). The $\alpha-\mathrm{Si}_{3} \mathrm{~N}_{4}$ seed in the present study was nitrided material that was generally of higher purity than the silicon 
powders used so impurity effects are negligible. It is a common practice to give these types of powders a hydrofluoric acid treatment to reduce the oxygen content and this may have contributed to the strength reduction due to oxidation. However, the results need to be confirmed to support such an explanation.

\section{CONCLUSIONS}

The type of silicon powder and sintering additive were found to influence the processing and final mechanical properties of sintered reaction bonded silicon nitride. High purity silicon powders produced low $\alpha-\mathrm{Si}_{3} \mathrm{~N}_{4}$ content during nitridation. The Si powder type had no apparent effect on densification. More complete nitridation and higher room temperature mechanical properties were observed for the Si powders with higher Fe contents. However, the higher Fe contents resulted in greater high temperature strength degradation and so there was better high temperature strength retention with the higher purity $\mathrm{Si}$.

High $\alpha-\mathrm{Si}_{3} \mathrm{~N}_{4}$ contents were found after nitridation with $\alpha-\mathrm{Si}_{3} \mathrm{~N}_{4}$ seeded materials and with $\mathrm{MgO}-\mathrm{Y}_{2} \mathrm{O}_{3}$ as the sintering additive. Densification was inhibited by refractory additives, such as $\mathrm{Y}_{2} \mathrm{O}_{3}-\mathrm{SiO}_{2}$. The highest room temperature strength and fracture toughness values correlated to high nitrided $\alpha-\mathrm{Si}_{3} \mathrm{~N}_{4}$ contents. The high temperature strength behavior was similar for all additive types.

\section{ACKNOWLEDGMENTS}

Research sponsored by the U.S. Department of Energy, Assistant Secretary for Energy Efficiency and Renewable Energy, Office of Transportation Technologies, as part of the Ceramic Technology Project of the Propulsion System Materials Program, under contract DE-AC05-96OR22464 with Lockheed Martin Energy Research Corp.

\section{REFERENCES}

1. L. M. Sheppard, "Cost-Effective Manufacturing of Advanced Ceramics," Am. Ceram. Soc. Bull., 70[4]692-707(1991).

2. A. J. Moulson, "Reaction-Bonded Silicon Nitride: Its Formation and Properties," J. Mater. Sci., Vol. 14, pp. 1017-1051 (1979)

3. F. L. Riley, "Nitridation and Reaction Bonding," pp. 265-288 in Nitrogen Ceramics, F. L. Riley (ed.), Noordhoff, Netherlands (1977)

4. J. A. Mangels and G. J. Tennenhouse, "Densification of Reaction-Bonded Silicon Nitride," Am. Ceram. Soc. Bull., 59 [12] 1216-1222 (1980).

5. J. A. Mangels, "Sintered Reaction-Bonded Silicon Nitride," Ceram. Eng. Sci. Proc., 2[7-8] 589-603 (1981).

6. L. K. L. Falk, R. Pompe, G. L. Dunlop, "Development of Microstructure During the Fabrication of $\mathrm{Si}_{3} \mathrm{~N}_{4}$ by Nitridation and Pressureless Sintering of Si:Si ${ }_{3} \mathrm{~N}_{4}$ Compacts," J. Mater. Sci., 20, 3545-3556 (1985).

7. T. N. Tiegs, J. O. Kiggans, and K. L. Ploetz, , "Cost-Effective Sintered Reaction-Bonded Silicon Nitride for Structural Ceramics," Ceram. Eng. Sci. Proc., 14[1-2] 378-388 (1993). 
8. R. Pompe and L. Hermansson, "Characterization of Silicon Powders for the Production of $\mathrm{Si}_{3} \mathrm{~N}_{4}$," Mater. Sci. Eng., 71, 355-362(1985).

9. P. L. Antona, A. Giachello, and P. C. Martinengo, "Nitridation of Silicon in the Presence of Oxides," pp. 753-766 in Ceramic Powders (ed. P.

Vincenzini), Elsevier Sci. Pub., Amsterdam (1983).

10. A. J. Pyzik, D. F. Carroll and C. J. Hwang, "The Effect of Glass Chemistry on the Microstructure and Properties of Self Reinforced Silicon Nitride, " pp. 411-416 in Silicon Nitride Ceramics, Edited by I-W. Chen, P. F. Becher, M. Mitomo, G. Petzow and T. S. Yen, Materials Research Society, Pittsburgh, PA (1993).

11. A. J. Pyzik and D. R. Beamen, "Microstructure and Properties of SelfReinforced Silicon Nitride, "J. Am. Ceram. Soc., 76[11]27372744(1993).

12. V. Tikare and S. R. Choi, "Influence of the Microstructure on Its R-Curve and Fatigue Behavior," Ceram. Eng. Sci. Proc., 12[7-8] 1437-1447 (1991).

13. I. P Tuersley, G. Leng-Ward, and M. H. Lewis, "High-Temperature $\mathrm{Si}_{3} \mathrm{~N}_{4}$ Based Ceramics," Brit. Ceram. Proc.,46. 231-246 (1990).

Table 1. Summary of compositions used for SRBSN study.

\begin{tabular}{llcc}
\hline Sample ID & Final Composition ${ }^{\mathrm{ab}}$ & $\begin{array}{c}\alpha-\mathrm{Si}_{3} \mathrm{~N}_{4} \\
\text { Content } \\
\text { (wt. \%) }\end{array}$ & $\begin{array}{c}\text { Si Powder } \\
\text { Fe Content } \\
\text { (wt. \%) }\end{array}$ \\
\hline \hline Elkem or A-Y & $\mathrm{Si}_{3} \mathrm{~N}_{4}-9 \% \mathrm{Y}_{2} \mathrm{O}_{3}-3 \% \mathrm{Al}_{2} \mathrm{O}_{3}$ & 10 & $0.29^{\mathrm{d}}$ \\
K.N. 4C & $\mathrm{Si}_{3} \mathrm{~N}_{4}-9 \% \mathrm{Y}_{2} \mathrm{O}_{3}-3 \% \mathrm{Al}_{2} \mathrm{O}_{3}$ & 10 & $0.1^{\mathrm{e}}$ \\
K.N. 5C & $\mathrm{Si}_{3} \mathrm{~N}_{4}-9 \% \mathrm{Y}_{2} \mathrm{O}_{3}-3 \% \mathrm{Al}_{2} \mathrm{O}_{3}$ & 10 & $0.018^{\mathrm{f}}$ \\
Albemarle & $\mathrm{Si}_{3} \mathrm{~N}_{4}-9 \% \mathrm{Y}_{2} \mathrm{O}_{3}-3 \% \mathrm{Al}_{2} \mathrm{O}_{3}$ & 10 & $0.001^{\mathrm{g}}$ \\
A-Y & $\mathrm{Si}_{3} \mathrm{~N}_{4}-9 \% \mathrm{Y}_{2} \mathrm{O}_{3}-3 \% \mathrm{Al}_{2} \mathrm{O}_{3}$ & 10 & $0.29^{\mathrm{d}}$ \\
A-Y* & $\mathrm{Si}_{3} \mathrm{~N}_{4}-9 \% \mathrm{Y}_{2} \mathrm{O}_{3}-3 \% \mathrm{Al}_{2} \mathrm{O}_{3}$ & 0 & $0.29^{\mathrm{d}}$ \\
M-Y & $\mathrm{Si}_{3} \mathrm{~N}_{4}-6.4 \% \mathrm{Y}_{2} \mathrm{O}_{3}-3.2 \% \mathrm{MgO}^{\mathrm{h}}$ & 10 & $0.29^{\mathrm{d}}$ \\
M-A-Y & $\mathrm{Si}_{3} \mathrm{~N}_{4}-5 \% \mathrm{Y}_{2} \mathrm{O}_{3}-5 \% \mathrm{MgAl}_{2} \mathrm{O}_{4}$ & 10 & $0.29^{\mathrm{d}}$ \\
Y-S & $\mathrm{Si}_{3} \mathrm{~N}_{4}-7.6 \% \mathrm{Y}_{2} \mathrm{O}_{3}-6.5 \% \mathrm{SiO}_{2}$ & 10 & $0.29^{\mathrm{d}}$ \\
\hline
\end{tabular}

${ }^{a}$ All compositions contained approximately $1.7 \mathrm{wt} \% \mathrm{SiO}_{2}$ to simulate typical $\mathrm{Si}_{3} \mathrm{~N}_{4}$ powder.

b $\mathrm{Y}_{2} \mathrm{O}_{3}$-Molycorp, White Plains, NY; Grade 5600, >99.99\%; $\mathrm{Al}_{2} \mathrm{O}_{3}$-Reynolds, Malakoff, TX, Grade RC-HP DBM; $\mathrm{MgAl}_{2} \mathrm{O}_{4}$, Ceralox, Tucson, AZ; MgO, Mallinckrodt, St. Louis, MO, Reagent Grade; $\mathrm{SiO}_{2}$, U. S. Silica, $5 \mu \mathrm{m}$.

'Starck, Berlin, Germany; Grade LC-10N. The $10 \%$ is based on $\mathrm{Si}_{3} \mathrm{~N}_{4}$ content after nitridation.

${ }^{d}$ Elkem Metals Co., Buffalo, NY; Grade Metallurgical Si; $3.4 \mu \mathrm{m}$ mean particle size.

${ }^{\mathrm{e}}$ KemaNord, Stockholm, Sweden, Grade $4 \mathrm{C} ; 6.4 \mu \mathrm{m}$ mean particle size.

${ }^{f}$ KemaNord, Stockholm, Sweden, Grade $5 \mathrm{C} ; 6.2 \mu \mathrm{m}$ mean particle size.

${ }^{g}$ Albemarle Corp., Baton Rouge, LA; $0.35 \mu \mathrm{m}$ mean particle size.

${ }^{\text {h}}$ Sample also contained $0.2 \% \mathrm{CaO}$ added as $\mathrm{CaCO}_{3}$. 

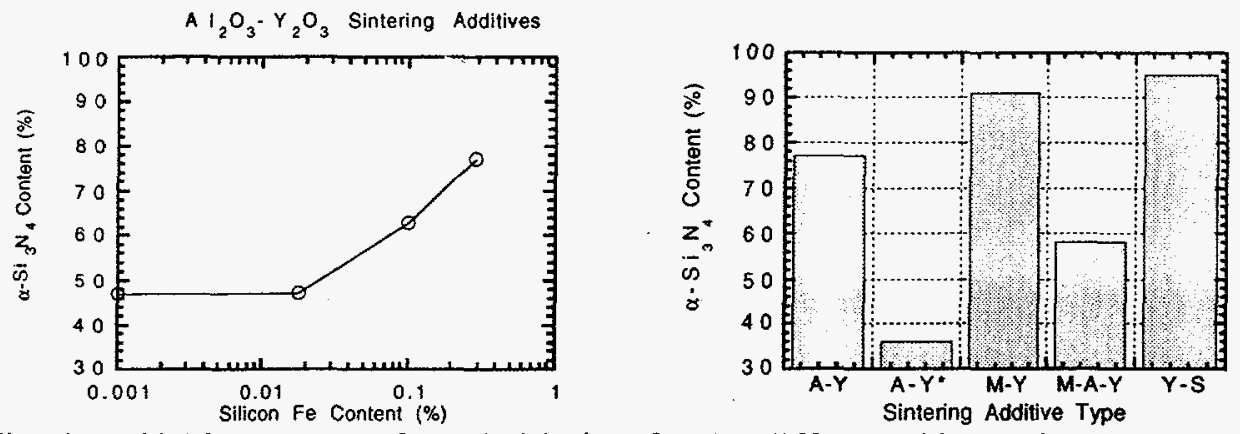

Fig. 1. $\alpha-\mathrm{Si}_{3} \mathrm{~N}_{4}$ content after nitridation for (a) different Si powder types correlated with starting $\mathrm{Fe}$ content, and (b) alternate sintering additives. Sample designations listed in Table 1 .
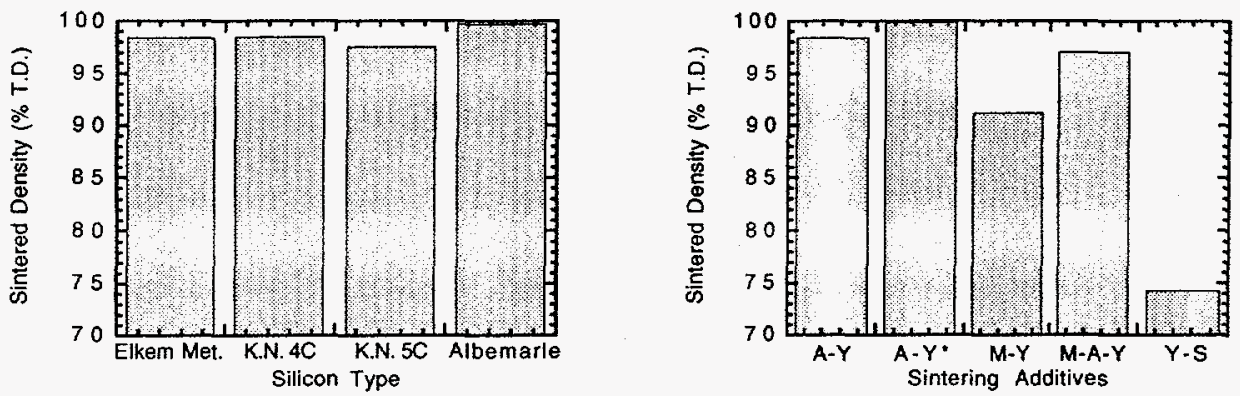

Fig. 2. Summary of densification results on (a) different Si powder types, and (b) alternate sintering additives. Sample designations listed in Table 1.
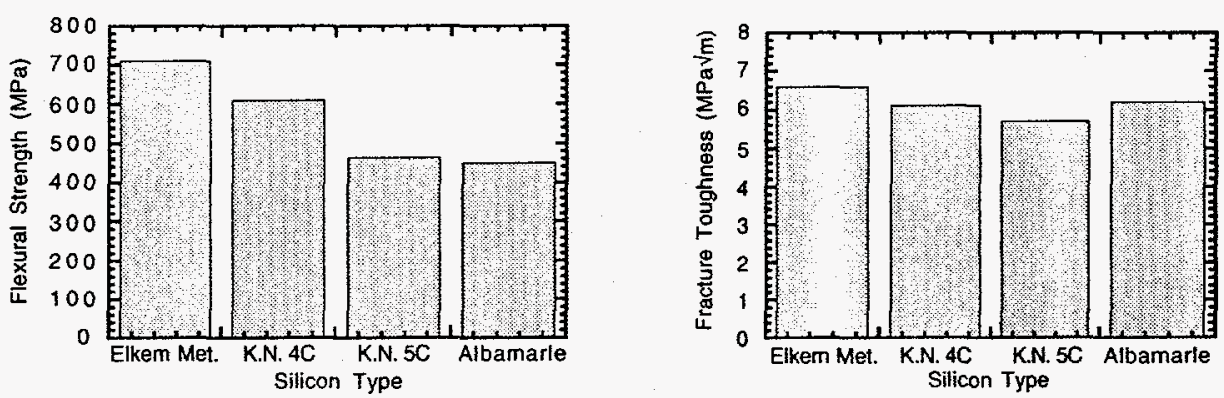

Fig. 3. Room temperature flexural strength (a) and fracture toughness (b) of SRBSN from different $\mathrm{Si}$ powder types. Additive composition was $\mathrm{Si}_{3} \mathrm{~N}_{4}-9 \%$ $\mathrm{Y}_{2} \mathrm{O}_{3}-3 \% \mathrm{Al}_{2} \mathrm{O}_{3}$. Sample designations listed in Table 1 . 

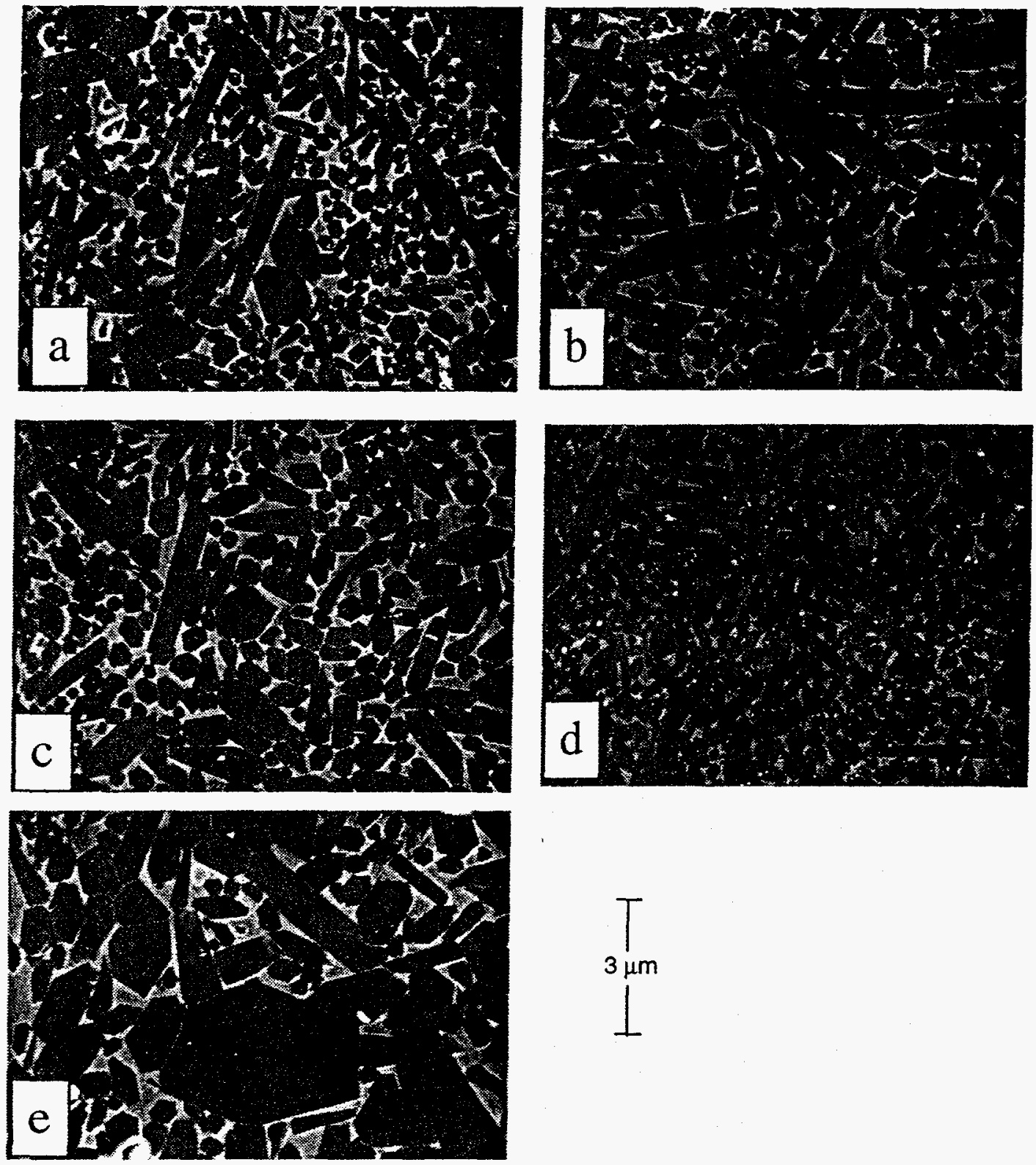

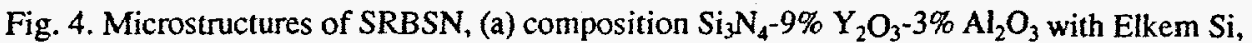
(b) composition $\mathrm{Si}_{3} \mathrm{~N}_{4}-9 \% \mathrm{Y}_{2} \mathrm{O}_{3}-3 \% \mathrm{Al}_{2} \mathrm{O}_{3}$ with KemaNord $4 \mathrm{C} \mathrm{Si}$, (c) composition $\mathrm{Si}_{3} \mathrm{~N}_{4}-9 \%$ $\mathrm{Y}_{2} \mathrm{O}_{3}-3 \% \mathrm{Al}_{2} \mathrm{O}_{3}$ with Elkem Si and no $\alpha$-seed, (d) composition $\mathrm{Si}_{3} \mathrm{~N}_{4}-5 \% \mathrm{Y}_{2} \mathrm{O}_{3}-5 \% \mathrm{MgAl}_{2} \mathrm{O}_{4}$ with Elkem $\mathrm{Si}$, (e) composition $\mathrm{Si}_{3} \mathrm{~N}_{4}-6.4 \% \mathrm{Y}_{2} \mathrm{O}_{3}-3.2 \% \mathrm{MgO}$ with Elkem $\mathrm{Si}$. 

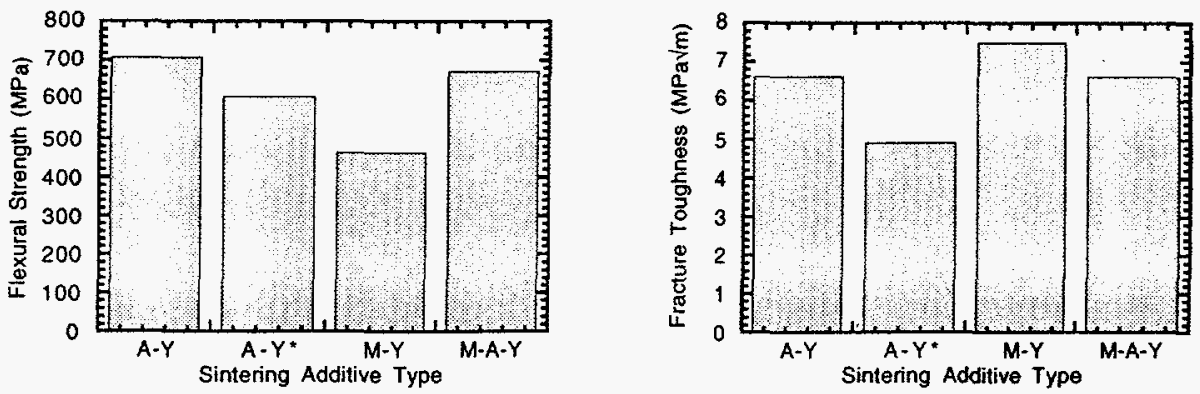

Fig. 5. Room temperature flexural strength (a) and fracture toughness (b) of SRBSN with alternate sintering additives. Sample designations listed in Table 1.

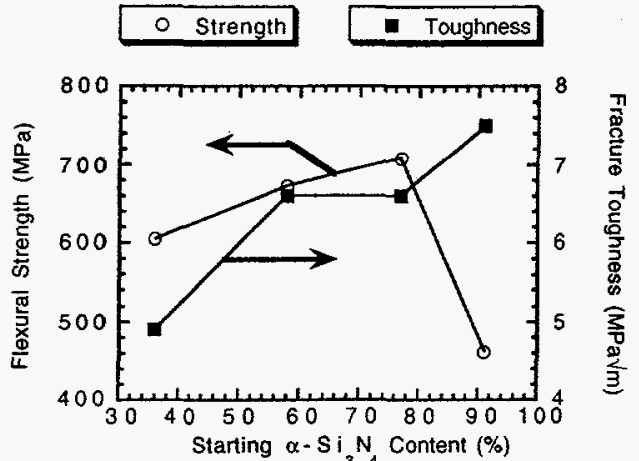

Fig. 6. Correlation of flexural strength and fracture toughness with starting $\alpha-$ $\mathrm{Si}_{3} \mathrm{~N}_{4}$ content after nitridation for SRBSN with alternate sintering additives.. Sample designations listed in Table 1.
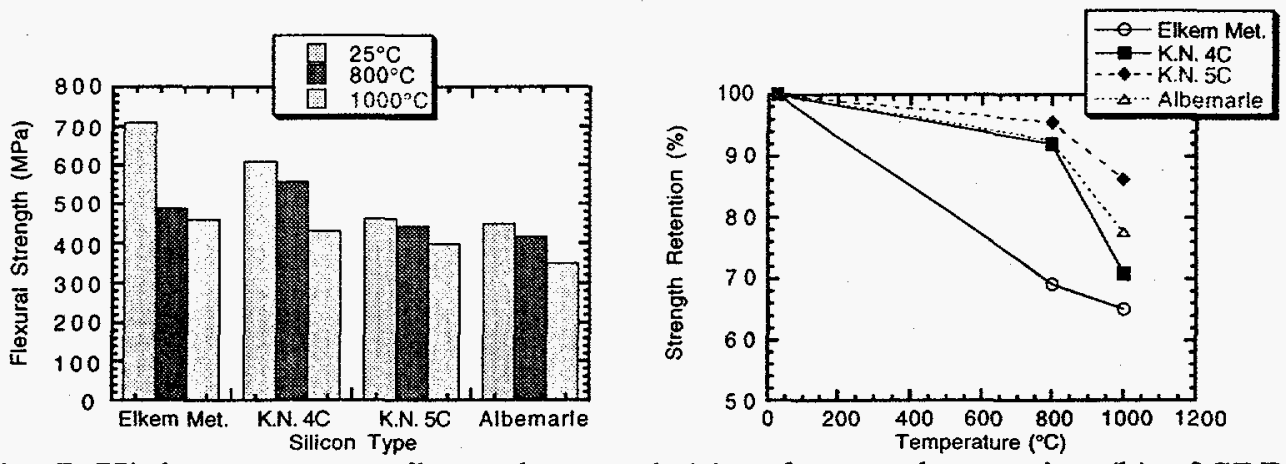

Fig. 7. High temperature flexural strength (a) and strength retention (b) of SRBSN from different $\mathrm{Si}$ powder types. Additive composition was $\mathrm{Si}_{3} \mathrm{~N}_{4}-9 \% \mathrm{Y}_{2} \mathrm{O}_{3}-3 \%$ $\mathrm{Al}_{2} \mathrm{O}_{3}$. Sample designations listed in Table 1. 

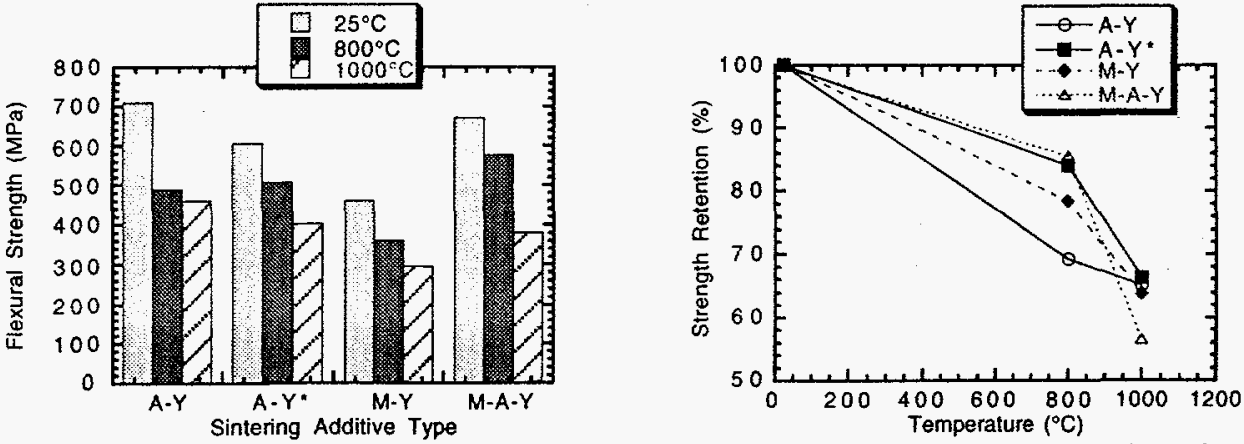

Fig. 8. High temperature flexural strength (a) and strength retention (b) of SRBSN with alternate sintering additives. Sample designations listed in Table 1.
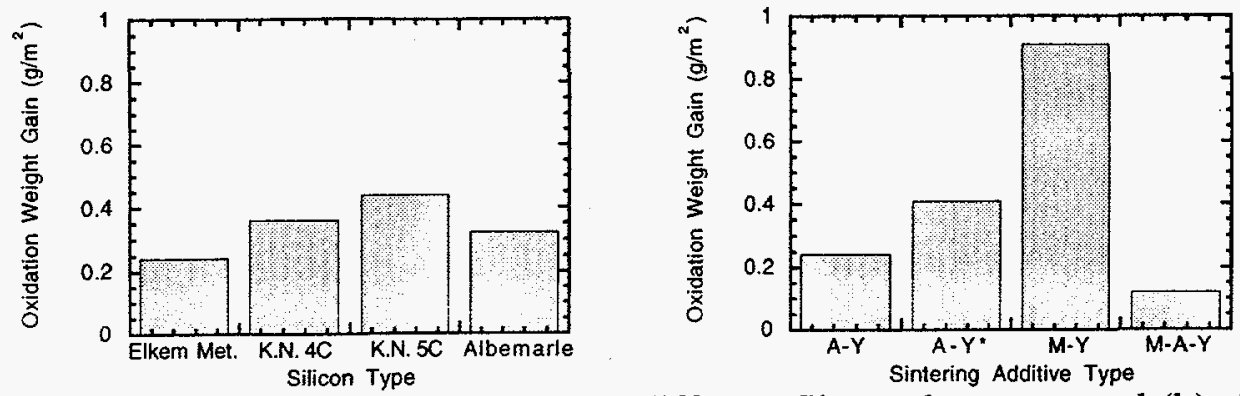

Fig. 9. Oxidation weight gains for (a) different Si powder types, and (b) alternate sintering additives. Oxidation at $1000^{\circ} \mathrm{C}$ for 100 hours in air. Sample designations listed in Table 1.
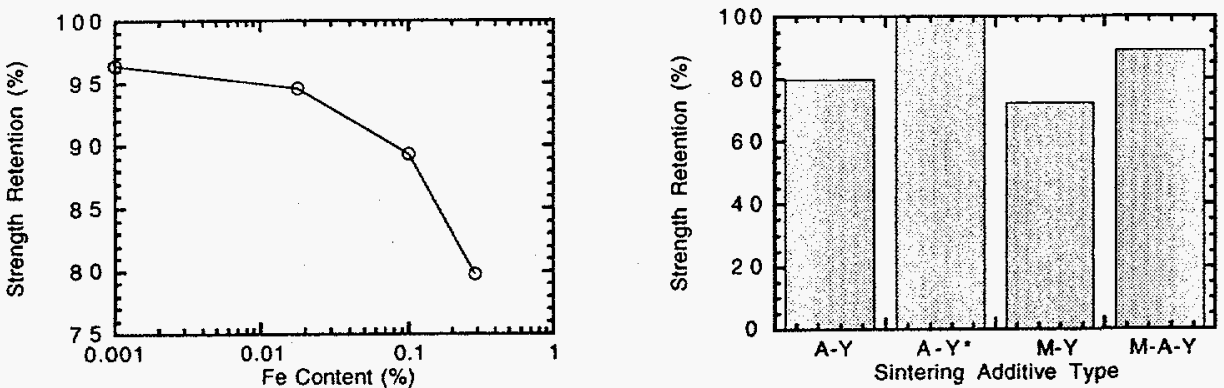

Fig. 10. Strength retention after oxidation for (a) different $\mathrm{Si}$ powder types correlated with starting Fe content, and (b) alternate sintering additives. Oxidation at $1000^{\circ} \mathrm{C}$ for 100 hours in air. Sample designations listed in Table 1.

\section{DISCLAIMER}

This report was prepared as an account of work sponsored by an agency of the United States Government. Neither the United States Government nor any agency thereof, nor any of their employees, makes any warranty, express or implied, or assumes any legal liability or responsibility for the accuracy, completeness, or usefulness of any information, apparatus, product, or process disclosed, or represents that its use would not infringe privately owned rights. Reference herein to any specific commercial product, process, or service by trade name, trademark, manufacturer, or otherwise does not necessarily constitute or imply its endorsement, recommendation, or favoring by the United States Government or any agency thereof. The views and opinions of authors expressed herein do not necessarily state or reflect those of the United States Government or any agency thereof. 